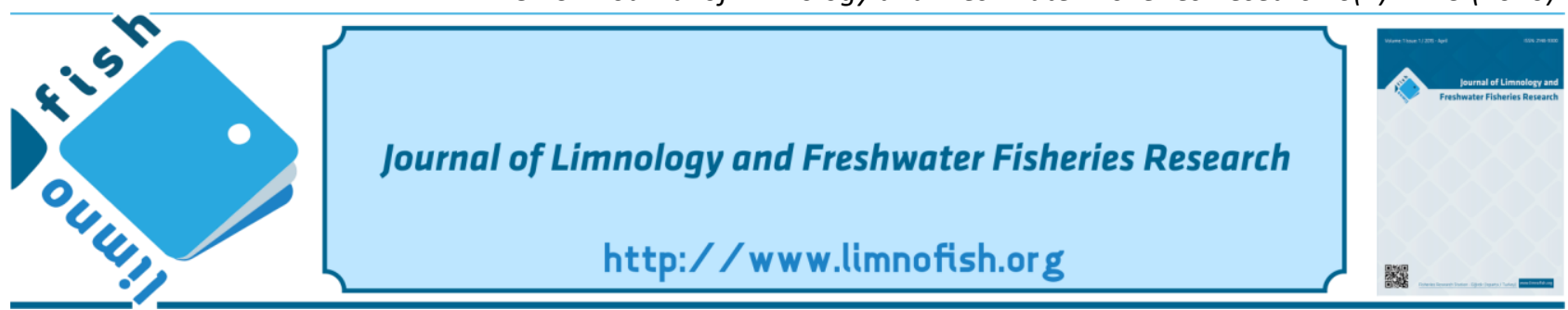

\title{
Efficiency and Suitability of the Fish Passages of River Ceyhan, Turkey
}

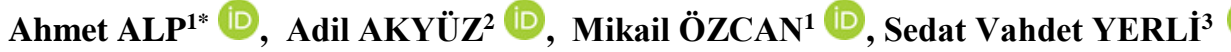 \\ ${ }^{1}$ University of Kahramanmaraş Sütçü İmam, Faculty of Agriculture, Department of Fisheries, Kahramanmaraş, Turkey \\ ${ }^{2}$ University of Kahramanmaraş Sütçü İmam, Faculty of Agriculture, Department of Biosystem Engineering, Kahramanmaraş, \\ Turkey \\ ${ }^{3}$ Hacettepe University, Department of Biology, SAL Ankara, Turkey
}

\section{A B STRACT}

The efficiencies of the two fish passages of River Ceyhan (Turkey) were investigated by using trap catches, external tags (T-bar anchor tags), PIT telemetry and radio telemetry. According to the results of the study, the pool and weir type fish passage were not effective; no fish entered the trap in this fish passage. Further, it was observed that none of the 50 external tagged fishes, 44 PIT-tagged fishes, and 47 radio-tagged fishes passed through this fish passage. A total of 900 Capoeta damascina and 520 Alburnus adanensis entered the trap installed in the vertical slot fish passage. A relationship was found between the gender ratio of the migratory $C$. damascina and their migration times. Fish passage performance was different according to the applications. These differences in fish passage success among the applications originated from the sizes of the tagged fish. Because the sizes of the radio-tagged fish were much larger than that of the external tagged fish and PIT-tagged fish so the success of the fish passage according to the radio telemetry was estimated higher than that of the other applications. The further passing ratio of the fish over $20 \mathrm{~cm}$ in length was higher than that of the small individuals.

\section{ARTICLE INFO}

\section{RESEARCH ARTICLE}

$\begin{array}{lll}\text { Received } & : 11.09 .2019 \\ \text { Revised } & : 01.11 .2019 \\ \text { Accepted } & : 04.11 .2019 \\ \text { Published } & : 25.04 .2020\end{array}$

DOI:10.17216/LimnoFish.618924

\section{* CORRESPONDING AUTHOR}

aalp@ksu.edu.tr

Keywords: Fish passage, fish migration, efficiency, trap, telemetry

\section{Ceyhan Nehri’ndeki (Türkiye) Balık Geçitlerinin Etkinlikleri ve Uygunlukları}

Öz: Ceyhan Nehir havzasında bulunan iki balık geçidinin etkinlikleri trap uygulaması, dıştan takma markalamalar (T-bar anchor tag), PIT telemetri ve radio telemetri yöntemleri ile incelenmiştir. Çalışma sonuçlarına göre havuzlu ve orifisli balık geçidine yerleştirilen trapta hiç bir balık tespit edilememiş olduğundan bu balık geçidinin etkinliğinin olmadığı belirlenmiştir. Ayrıca 50 adet dıştan takma marka, 44 adet PIT marka ve 47 adet radio markası taşıan balıklardan hiç birinin bu balık geçidinden geçmediği görülmüştür. Dikey yarıklı balık geçidine yerleştirlen trapta ise toplam 900 Capoeta damascina ve 520 Alburnus adanensis tespit edilmiştir. Göç yapan $C$. damascina bireylerinin cinsiyet oranları ile göç zamanları arasında bir ilişsi tespit edilmiştir. Uygulanan yöntemlere göre balık geçidinin performansı farklılık göstermiştir. Bu farklılık markalanan balıkların boylarının farklı olmasından kaynaklanmıştır. Çünkü radyo taglarla markalanan balıkların boyları PIT taglarla ve dıştan takma markalarla markalanan balıklardan daha büyüktü ve bu nedenle radyo telemetri yöntemine göre hesaplanan balık geçidi performansı diğer yöntemlere göre daha yüksek bulunmuştur. Ayrıca, 20 cm'den büyük balıkların balık geçidinden geçme performansı küçük balıklara göre daha yüksek olmuştur.

Anahtar kelimeler: Balık geçidi, balık göçü, etkinlik, trap, telemetri

How to Cite

Alp A, Akyüz A, Özcan M, Yerli SV. 2020. Efficiency and Suitability of the Fish Passages of River Ceyhan, Turkey. LimnoFish. 6(1): 1-13. doi: 10.17216/LimnoFish.618924

\section{Introduction}

River habitats that have important roles for the sustainability of fish populations are negatively affected by engineering structures such as dams and hydropower plants built on rivers (Larinier 2000; Marmulla 2001; Jackson and Marmulla 2001). Hydropower plants have to be environmentally friendly; hydroelectric power plant projects should consider fish migrations in river basins. A suitable fish passage ensures the migration of fish between zones of the feeding and spawning. Otherwise, fish stocks decline, certain fish species become extinct or fragmented populations come into the picture (Larinier 2000; Roscoe and Hinch 2010). Various designs of fish passages have been developed in the past to enable fish to pass barriers and to minimize 
the impacts of the obstructions (Roscoe and Hinch 2010). The first known attempts to build fish passages were older than the development of hydropower itself and were constructed in Europe more than 300 years ago (Clay 1995; Calles and Greenberg 2005; Katopodis and Williams 2012). First written documents about fish passages goes back to 1870s (Worral 1874; Rogers 1892; Cheney 1898; Buck 1906, 1913; Dyche 1912; Prince 1914; Larinier et al. 2002; Roscoe and Hinch 2010; Bunt et al. 2012; Williams et al. 2012; Brown et al. 2013).

The most important impacts of the construction of reservoirs are on the ichthyofauna, especially on migratory fish. The impacts are due to the interception of migratory routes, alteration of the hydrological regime, and reduction of spawning and nursery habitats (Wagner et al. 2012; Agostinho et al. 2004). The observations for the fish passages in Turkey have shown that they were constructed without proper assessment and usage of basic scientific knowledge on the fish species of concern. Although more than 370 fish species inhabit Turkish inland waters (Kuru et al. 2014), there is no proper inventory for migratory fish species. Contemporary literature does not provide proper information on habitat usages and hydrological requirements of inland water fish in Turkey. However, it is a wellknown fact that an effective fish passage design requires extensive integration of biological and hydrological data in addition to other physical data (Castro-Santos et al. 2009).

State-owned large dams have been built in Turkey within the past 60 years and almost none has proper fish passages. Anguilla anguilla has disappeared in the inland sections of Turkey. It only inhabits lower sections of rivers downstream of dams with lowest altitudes and coastal lagoons since migrations of fish were not ensured by large dam projects. Sturgeon in the Black Sea Region is also almost extinct because of the lack of fish passages near dam structures. The first fish passage of Turkey was built on Seyhan Regulator in 1939 and the second one was built on Emiralem Regulator in 1944. These passages and other 35 passages were been constructed by the General Directorate of State Hydraulic Works (DSI 2013). All these fish passages were built on the small regulators and no fish passage is present on other 596 large dams. Additionally, more than 1250 small scale and relatively new hydroelectric power plants have been erected by private companies since 2001. The Turkish Fisheries Code no: 1380 requires these small scale hydroelectric power plants belonging to the private sector have to have fish passages. These fish passages are often pool and weir, and vertical slot type rather than Denil type. Unfortunately, there is no database as related to the effectiveness of present fish passages. The number of studies on the evaluation of fish passages in the World reached to considerable level (96 studies from America, Europe, and Australia) and $76 \%$ of the articles in journals were published between 1999 and 2008 (Roscoe and Hinch 2010). Nearly all studies focused on efficiency questions while some of them included mechanisms, consequences, and physiology. So far, a few studies have been conducted on the evaluation of the effectiveness of fish passages in Turkey (Alp et al. 2018; Kucukali et al. 2019). Some telemetry methods such as PIT telemetry, radio telemetry, and video monitoring systems have been applied to investigate the efficiency of fish passages (Castro-Santos et al. 1996; Lucas et al. 1999; Riley et al. 2010; Roscoe and Hinch 2010).

Turkish inland waters have more than 370 fish species and about more than 100 of them are endemic (Kuru et al. 2014). From these species, two of them (sturgeon and Black Sea trout) are anadromous and also one species (Anguilla anguilla) is catadromous. The contemporary literature does not offer enough information about the potamodromous species and their migrations. Further, there is a lack of knowledge about the effects of hydropower applications on the potamodromous species.

The effectiveness of the fish passages in two streams of River Ceyhan (Turkey) was studied to collect data about the fish species and passage performances within the scope of this specific research. The results of the study may hopefully be used to apply more effective fish conservation strategies by designing better and more suitable fish passages to reduce the ecological problems created by hydropower plants. To achieve the goal of the research, following enlisted data were obtained about the fish passed through the fish passages; a) migratory fish species, $b$ ) the number of the migrated fishes, c) the sizes of the migrated fish, d) genders of the migrated fishes e) migration seasons and migration durations and $f$ ) the performances of the fish passages.

\section{Materials and Methods \\ Study site}

Ceyhan River Basin is in the Eastern Mediterranean region of Turkey and is bordered by Seyhan Basin in the west and northwest, Asi Basin in the south and Firat Basin in the east and northeast. The river drains into the Mediterranean Sea in the south. Ceyhan River Basin area is $20670 \mathrm{~km}^{2}$ and its mean annual flow volume is 7.18 billion cubic meters. This corresponds to $4 \%$ of the total river discharge to Turkey (Agrin Co. Ltd. 1999; Tanrıverdi et al. 2010). 
A total of 9 large dams belonging to the state were built in Ceyhan River Basin and none of these has a fish passage (Figure 1). Anguilla anguilla has been extinct in the middle and upper sections of the Ceyhan River basin (Kara et al. 2010). In addition to these large dams, a total of 50 small scale hydropower plants were constructed by private companies in Ceyhan River Basin (Figure 1). Only 16 of these small-scale hydropower plants have fish passage facilities. They are pool and weir type (5 fish passages), vertical slot type (10 fish passages) and Denil type (1 fish passage). Fish fauna of the Ceyhan River consists of 20 species belonging to 10 families (Kara et al. 2010).

A vertical slot type fish passage from Tekir Stream and a pool and weir type fish passage from Firnız Stream of Ceyhan River were studied in this study. Vertical slot fish passage was $126 \mathrm{~m}$ in length and $14.10 \mathrm{~m}$ in height with a slope of $11.19 \%$. It includes 63 pools and its pool dimensions were 140 by $200 \mathrm{~cm}$ with two water inlets for fish exit from upstream. Pool and weir fish passage was $25.43 \mathrm{~m}$ in length and $4.5 \mathrm{~m}$ in height with a slope of $17.70 \%$. It has 16 pools and one water inlet from the upstream site and orifices sizes were 30 by $30 \mathrm{~cm}$.

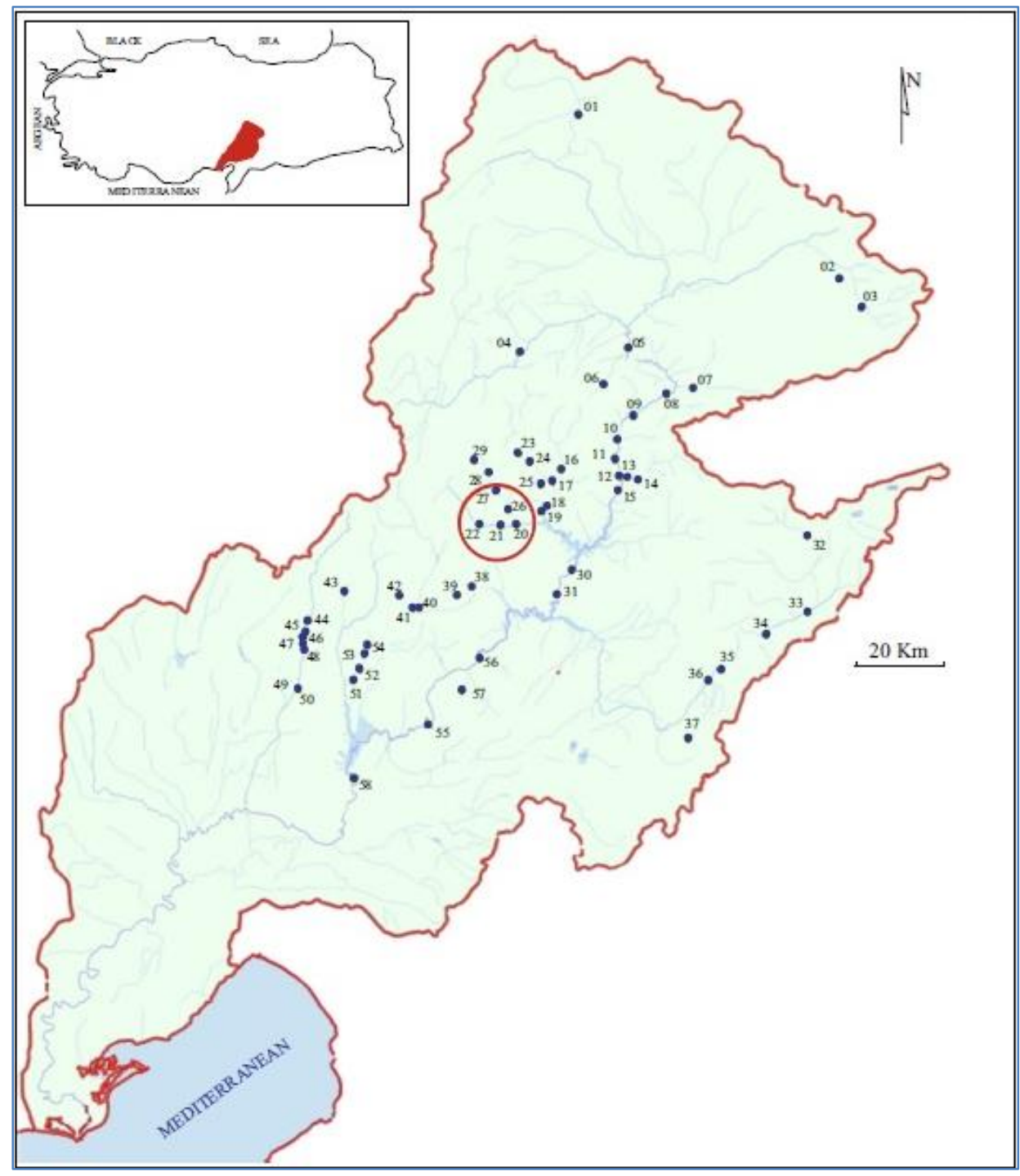

Figure 1. Ceyhan River Basin and distribution of hydropower plants.

*Studied streams are circled by red line:(1. Karakuz HES, 2. Söğütlü 1 HES, 3. Kantarma HES, 4. Adatepe HES, 5. Dağdelen HES, 6. Köyobası HES, 7. Uzuntepe HES, 8. Kandil 1 HES, 9.(Kandil 2 HES, 10. Sarı̈üzel 1 HES, 11. Sarıüzel 2 HES, 12. Çakmak 2 HES, 13. Söğütlü HES, 14. Çakmak 1 HES, 15. Hacınınoğlu HES, 16. Okkayası ve Şehitlik HES, 17. Süleymanlı HES, 18. Zeytin HES, 19. Kozak HES, 20. Suçatı HES, 21. Fırnız HES, 22. Așağı Fırnız HES, 23. Sisne HES, 24. Sivritaş HES,25. Avcılar HES, 26. Çamlık HES, 27. Çataloluk HES, 28. Kısık HES, 29. Üçkaya HES, 30. Menzelet HES,31. Kılavuzlu HES, 32. Aksu HES, 33. Akpınar HES, 34. Nur HES, 35. Kartalkaya HES, 36. Kesme HES,37. Yaş1l HES, 38. Torlar HES, 39. Gökgedik HES, 40. Kale HES, 41. Karasu HES, 42. DeğirmenüstüHES, 43. Teytur HES, 44. Tahta HES, 45. Karapınar HES, 46. Andırın HES, 47. Kargılık HES, 48. Bulgurkaya HES, 49. Tayfun Kanal HES, 50. Damlasu HES, 51. Poyraz HES, 52. Sazak HES, 53. Çatak HES, 54. Güneşli HES, 55. Berke (Değirmen) HES, 56. Sir HES, 57. Güvercin HES, 58. Aslantas HES) 


\section{Determination of the migratory species}

Traps were installed into fish passages to determine fish species and the number of the individuals passing through the fish passage, their sizes, genders and migration periods. The size of the traps was determined considering the dimensions of the fish passages and they were made of a metal frame box including a cone and $0.5 \mathrm{~cm}$ stretched mesh size. Traps were set up into third pools at the top side of the fish passage so that fish could not pass through the edges of the trap. They were controlled routinely and the caught fish with traps were taken into a tank and then they were anesthetized with 2phenoxy ethanol. For each species, the total number and the genders of the fishes were determined; their lengths were measured. Following recovery and gaining swimming ability, they were released into the upper pool of the fish passage. A Hobo Onset sensor was installed into the fish passage and the water temperature was recorded for each half an hour.

\section{Evaluation of efficiencies of fish passages}

External tags (T-Bar anchor tags), PIT telemetry (passive integrated transponder (PIT) tags) and radio telemetry methods were the adopted methods to achieve the goals of the research.

\section{a) External tag application}

The fish were caught by electro shocker at downstream of fish passage. They were anesthetized with 2-phenoxy ethanol, measured and tagged with T-Bar anchor tags from the base of dorsal fin using a tag gun. A total of 172 fishes (122 fish in Tekir Stream and 50 fish in Firnı Stream) were tagged with T-Bar anchor tags. The traps into the fish passages were controlled routinely and T-Bar anchor tagged fish into the traps were recorded, counted and then released to the upper pool of the fish passage.

\section{b) PIT telemetry}

Fishes were caught by electro shocker at downstream of fish passage and they were anesthetized with 2-phenoxy ethanol and then measured. A total of 200 fish (156 fish in Tekir Stream and 44 fish in Firnız Stream) was tagged with a passive integrated transponder (PIT) tags by a tag gun and released to the downstream of fish passage. All PIT tags were HPT 12 model tags and they were $12 \mathrm{~mm}$ in length and with $134.2 \mathrm{kHz}$. To detect PIT-tagged fish passed through the fish passage, a square antenna (80x80 $\mathrm{cm}$ in dimension) was placed into the fish passage and the system was linked to an HPR Reader system. The detection range for a standard $12 \mathrm{~mm}$ PIT tag was reported to be $15.2-25.4 \mathrm{~cm}$ from the antenna (Reagan et al. 2005). All PIT telemetry equipment was produced by BIOMARK Company (Boise-Idaho, USA).

\section{c) Radio telemetry}

A total of 73 fishes (47 fishes in Firniz Stream and 26 fishes in Tekir Stream) caught by electro shocker from downstream of fish passages were tagged with cylindrical radio transmitters (Lotek Wireless Inc, Model MST-930) with the sizes of 26 mm length by $9.5 \mathrm{~mm}$ width and with $4.5 \mathrm{~g}$ weight. The expected battery life of the transmitters was 266 days with a signal transmit at 5 seconds interval for 24 hours. However, the battery life of the transmitters was extended to 385 days by the programming of "on" 12 hours / "off" 12 hours. The frequencies of the transmitters used were preferred between 149.420 and $150.320 \mathrm{MHz}$. Each transmitter had a unique code that allowed for individual identification.

The fish were anesthetized with 2-phenoxy ethanol $\left(0.5 \mathrm{ml} \mathrm{l}^{-1}\right.$ water $)$, measured and transmitters were surgically implanted into fishes on a $\mathrm{V}$-shaped surgery table. During the surgery operation, the lower anesthetic concentration of water $\left(0.4 \mathrm{ml} \mathrm{l}^{-1}\right.$ water $)$ was given from the mouth of the fish by a pipe so that the gills were constantly kept wet. The transmitters were inserted into the body cavity through a ventral 10 to $15 \mathrm{~mm}$ incision and then it was closed with three sutures. The antenna was pushed through the body wall using a hollow needle (Thorsteinsson 2002; Ramstad and Woody 2003; Fredrich et al. 2003; Jepsen et al. 2005; Lucas and Bubb 2005; Thorstad et al. 2013). Radio tagged fish were tracked by Lotek SRX 400 radio receiver and yagi antenna, and the tagged fish passed through the fish passage were recorded.

\section{Results}

\section{Migratory fish species ascending through the fish passage}

\section{Trap placement}

Traps were installed into fish passages in Firnız Stream and Tekir Stream on the $20^{\text {th }}$ of April 2012 and 2013, respectively. Traps were operated during 84 days in 2012 between April $20^{\text {th }}$ and July $13^{\text {th }}$; during 79 days in 2013 between April $20^{\text {th }}$ and July $8^{\text {th }}$. No fish have been detected in traps installed into the pool and weir fish passage in Firnız Stream, for the above-mentioned periods.

A total of 428 Capoeta damascina and 262 Alburnus adanensis individuals ascended vertical slot fish passage in Tekir Stream in 2012 and they migrated towards upstream (Table 1). In 2013, 472 C. damascina and 258 A. adanensis ascended the same fish passage and migrated towards the upstream. Upstream migration of $C$. damascina lasted 63 days in 2012, between May $1^{\text {st }}$ and July $7^{\text {th }}$, while it was 46 days in 2013, between May $1^{\text {st }}$ and June $15^{\text {th }}$. Upstream migration of $A$. adanensis 
continued during 56 days in 2012, between May $8^{\text {th }}$ and July $3^{\text {rd }}$, and during 53 days in 2013 between May $1^{\text {st }}$ and June $23^{\text {rd }}$.
The major fish migration of both species occurred during the end of May and the beginning of June.

Table 1. The number of the fish into the traps in vertical slot fish passage and their sizes and gender ratios according to species and dates.

\begin{tabular}{|c|c|c|c|c|c|c|}
\hline \multirow[b]{2}{*}{ Date } & \multicolumn{3}{|c|}{ Capoeta damascina } & \multicolumn{3}{|c|}{ Alburnus adanensis } \\
\hline & $\mathrm{N}$ & $\begin{array}{l}\text { Total length } \\
\quad(\mathrm{cm})\end{array}$ & $\begin{array}{c}\text { Male-Female } \\
\text { (individual) }\end{array}$ & $\mathrm{N}$ & $\begin{array}{l}\text { Total length } \\
\qquad(\mathrm{cm})\end{array}$ & $\begin{array}{c}\text { Water temperature }\left({ }^{\circ} \mathrm{C}\right) \\
\text { Range }(\text { mean } \pm \mathrm{SD})\end{array}$ \\
\hline April 01, 2012 & 12 & $21.9 \pm 2.95$ & $10-2$ & 0 & & \\
\hline May 08,2012 & 47 & $20.6 \pm 2.08$ & $35-12$ & 8 & $15.7 \pm 1.83$ & \\
\hline May 21, 2012 & 165 & $22.7 \pm 3.46$ & $81-84$ & 42 & $15.4 \pm 1.59$ & \\
\hline June 06,2012 & 97 & $18.9 \pm 3.50$ & $39-58$ & 87 & $14.1 \pm 1.45$ & \\
\hline June 20, 2012 & 64 & $19.2 \pm 2.33$ & $21-43$ & 51 & $14.6 \pm 1.36$ & \\
\hline July 03,2012 & 43 & $18.9 \pm 1.42$ & $12-31$ & 74 & $14.8 \pm 1.47$ & \\
\hline July 13,2012 & 0 & & & 0 & & \\
\hline $\begin{array}{c}\text { Total } \\
\text { (Range) }\end{array}$ & 428 & $\begin{array}{l}20.9 \pm 3.77 \\
(13.0-43.0)\end{array}$ & $198-230$ & 262 & $\begin{array}{l}14.7 \pm 1.56 \\
(9.0-22.9)\end{array}$ & \\
\hline April 04, 2013 & 0 & & & 0 & & $10.2-12.2(10.7 \pm 0.58)$ \\
\hline April 23, 2013 & 0 & & & 0 & & $11.0-14.1(12.0 \pm 0.77)$ \\
\hline April 28, 2013 & 0 & & & 0 & & $12.6-16.4(14.1 \pm 1.06)$ \\
\hline May 01, 2013 & 24 & $18.5 \pm 2.82$ & $21-3$ & 18 & $14.0 \pm 1.44$ & $12.2-16.8(14.0 \pm 0.85)$ \\
\hline May 06, 2013 & 54 & $19.1 \pm 2.54$ & $33-21$ & 5 & $16.2 \pm 2.28$ & $11.0-17.5(13.6 \pm 1.54)$ \\
\hline May 17, 2013 & 145 & $19.7 \pm 2.81$ & $61-84$ & 18 & $16.6 \pm 2.45$ & $11.0-19.4(15.6 \pm 1.68)$ \\
\hline June 06,2013 & 231 & $19.4 \pm 5.02$ & $67-164$ & 185 & $15.8 \pm 2.06$ & $14.5-19.4(17.2 \pm 0.87)$ \\
\hline June 15,2013 & 18 & $18.6 \pm 3.01$ & $5-13$ & 27 & $16.8 \pm 2.65$ & $16.4-21.7(18.7 \pm 0.87)$ \\
\hline June 23, 2013 & 0 & & & 5 & $15.9 \pm 2.64$ & $18.3-22.3(19.1 \pm 0.83)$ \\
\hline July 08, 2013 & 0 & & & & & \\
\hline $\begin{array}{c}\text { Total } \\
\text { (Range) }\end{array}$ & 472 & $\begin{array}{l}19.4 \pm 2.98 \\
(11.2-39.8)\end{array}$ & $187-285$ & 258 & $\begin{array}{l}15.8 \pm 1.43 \\
(10.0-19.4)\end{array}$ & \\
\hline
\end{tabular}

The total lengths of $C$. damascina ascending fish passage varied between 13 to $43 \mathrm{~cm}$ with a mean of $20.9 \pm 3.77 \mathrm{~cm}$ in 2012 . The range was 11.2 to $39.8 \mathrm{~cm}$ with a mean of $19.4 \pm 2.98 \mathrm{~cm}$ in 2013 (Figure 2). The total lengths of
A. adanensis ascending the fish passage showed a variation between 9.0 and $22.9 \mathrm{~cm}$ with a mean of $14.7 \pm 1.56$ in 2012 . The range was 10.0 to $19.4 \mathrm{~cm}$ with a mean of $15.8 \pm 1.43 \mathrm{~cm}$ in 2013 (Figure 2). 

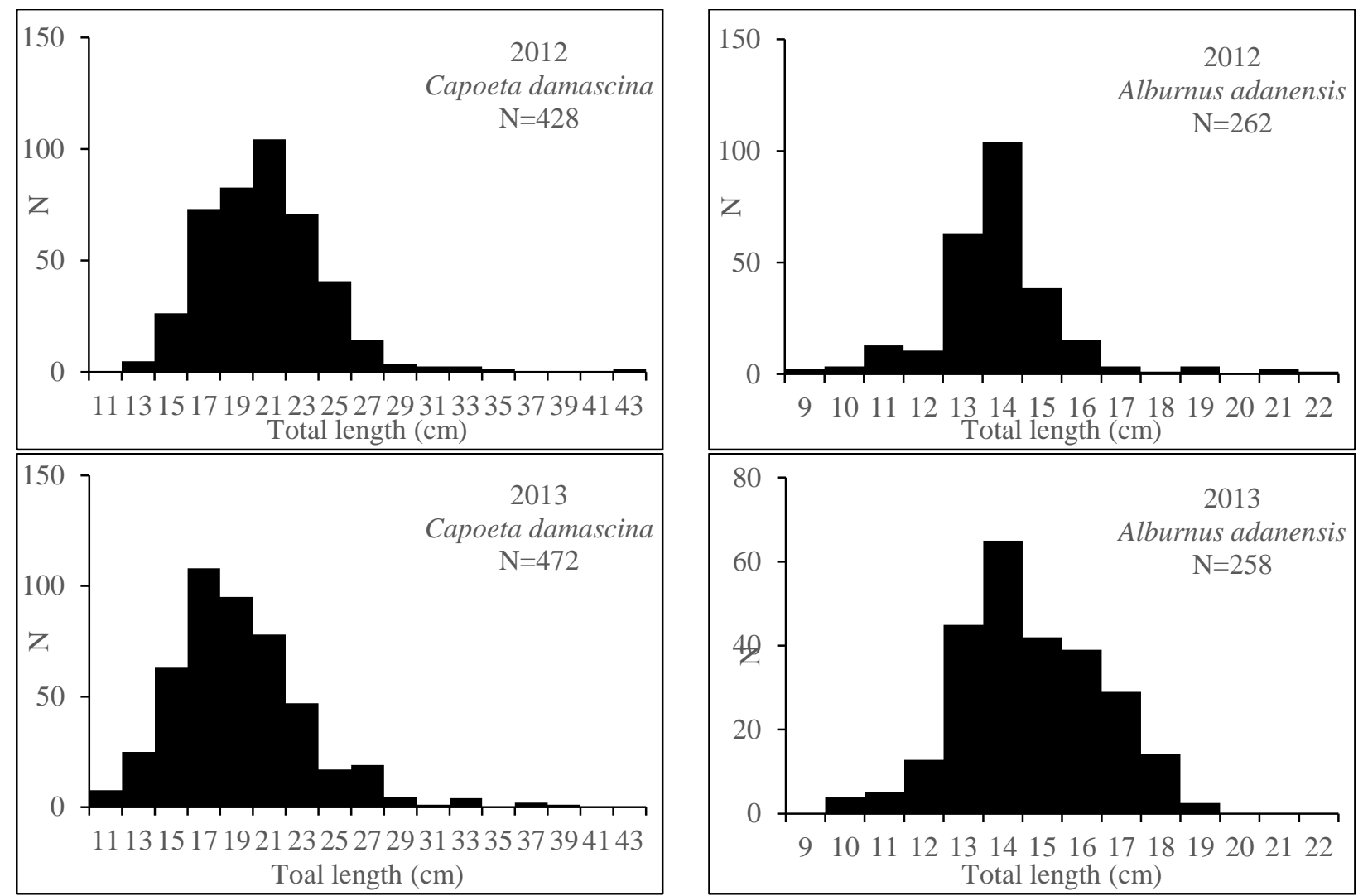

Figure 2. The length-frequency distribution of Capoeta damascina and Alburnus adanensis into the trap in vertical slot fish passage in 2012 and 2013.

The majority of the $C$. damascina were male individuals in the early days of the migration while towards the end of migration the rate of the males decreased, and the majority of the migratory individuals were females (Table 1). A relationship

was developed between the gender ratio of C. damascina individuals and the migration time (in days) with a coefficient of determination $=\mathrm{R}^{2}=0.97$ in 2012. $R^{2}$ was 0.93 for the developed relationship for 2013 (Figure 3).

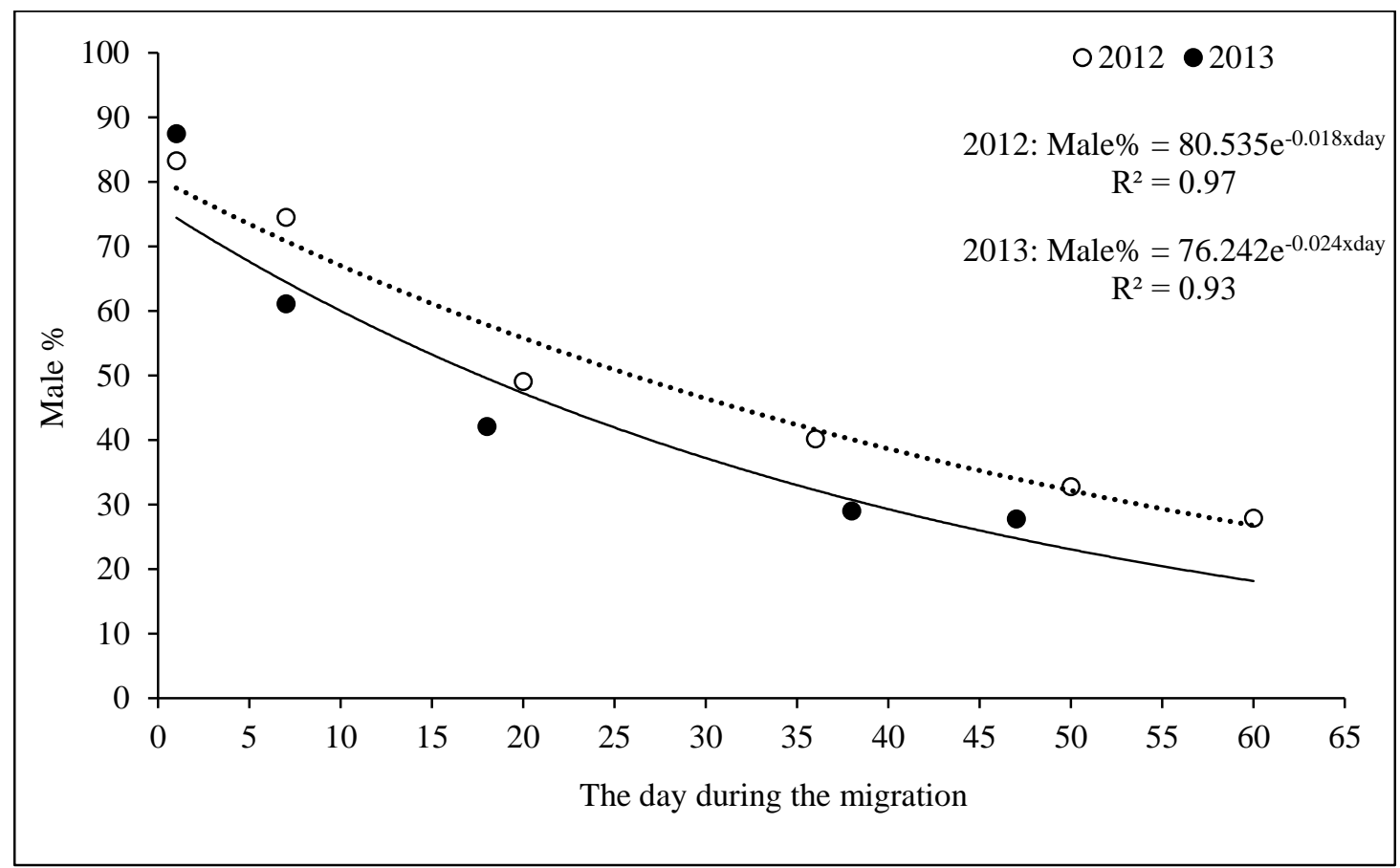

Figure 3. The gender ratios of Capoeta damascina obtained from the trap in the vertical slot fish passage according to the date in 2012 and 2013 
Water temperature in the fish passage varied from 4.6 to $24.8^{\circ} \mathrm{C}$ with a mean of $13.2^{\circ} \mathrm{C}$ on April $16^{\text {th }}$ of 2013 and on May $10^{\text {th }}$ of 2014. Water temperature varied from 12.2 to $22.3^{\circ} \mathrm{C}$ during the migration period (Table 1) and the majority of the migration took place with temperatures between 15 and $17{ }^{\circ} \mathrm{C}$.

\section{The efficiency of the fish passages}

a) External tagging (T-Bar anchor tags)
A total of 122 C. damascina in Tekir Stream and 50 C. damascina in Firnız Stream were tagged with T-bar anchor tags. The total lengths of the tagged fish in Firniz Stream varied from 14.8 to $39.6 \mathrm{~cm}$ with a mean of $23.6 \pm 2.97 \mathrm{~cm}$ and none of these tagged fish passed through fish passage of Firniz Stream. The total lengths of T-bar anchor tagged fish in Tekir Stream varied from 13.0 and $26.5 \mathrm{~cm}$ with a mean of $19.8 \pm 2.75 \mathrm{~cm}$ (Figure 4).
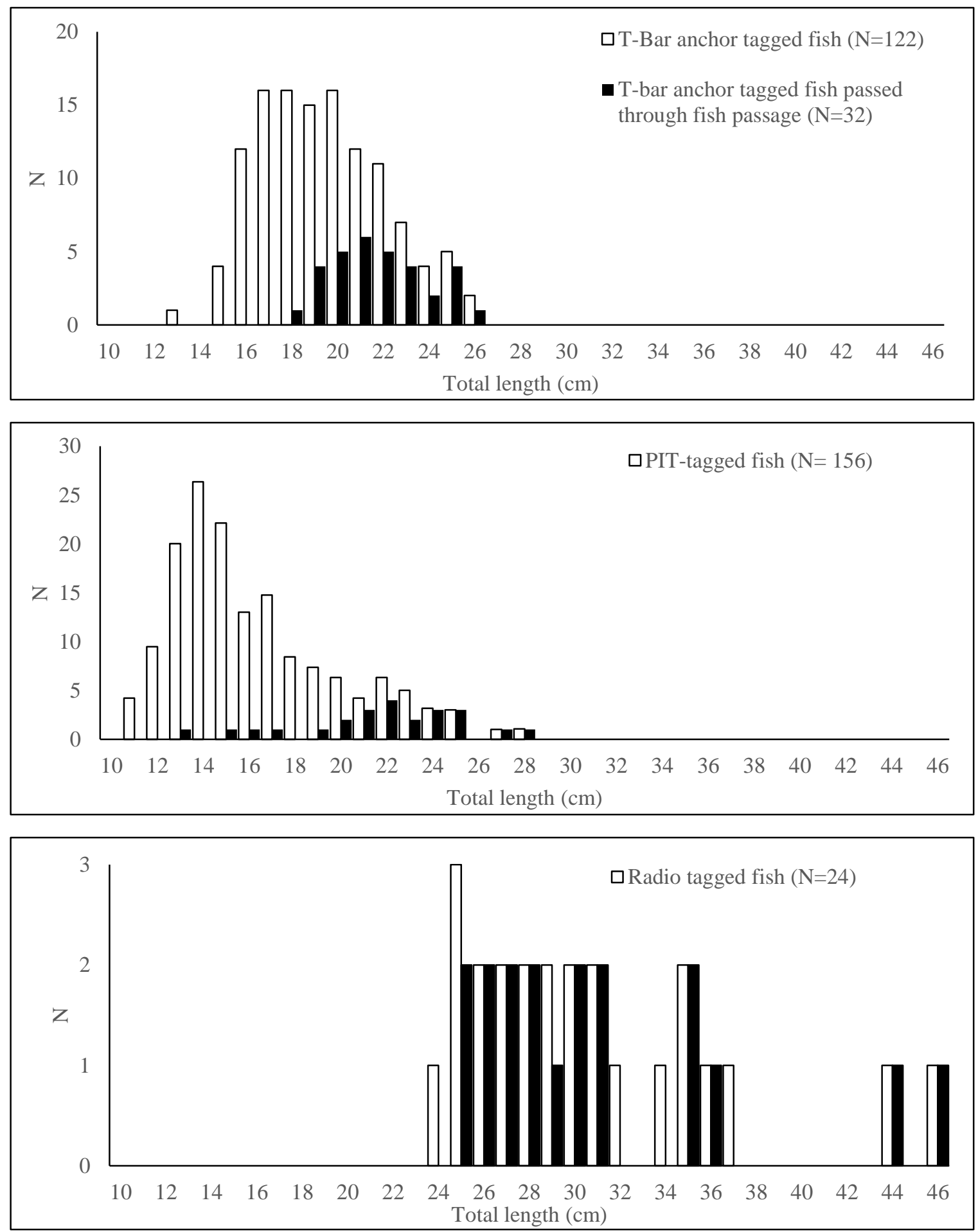

Figure 4. The length-frequency distribution of the tagged Capoeta damascina in Tekir Stream. 
Of the 122 T-bar anchor tagged fishes, 32 individuals ascended vertical slot fish passage in Tekir Stream corresponding to the ratio of $26.2 \%$. A total of 57 individuals from the 122 tagged $C$. damascina were over $20 \mathrm{~cm}$ in length and 27 of these (corresponding to $47.4 \%$ ) ascended fish passage.

The rate of the passing of small fish through the fish passage was lower than that of the larger ones. The total lengths of the fish ascending the fish passage varied from 18.6 to $26.0 \mathrm{~cm}$ with a mean of $22.1 \pm 2.10 \mathrm{~cm}$. The total length of the fish that didn't pass through fish passage varied from 13.0 to $26.5 \mathrm{~cm}$ with a mean of $19.0 \pm 2.49 \mathrm{~cm}$. The total length of the fish passed through the fish passage differed from the length of the fish that didn't pass the fish passage $(t=6.343, \mathrm{df}=120 ; p=0.000)$.

\section{b) PIT telemetry}

A total of 200 C. damascina were tagged with PIT tags. A total of 156 of them were from Tekir Stream and 44 of them were from Firnız Stream. The lengths of the PIT-tagged fish in Firnız Stream varied from 13.4 to $41.1 \mathrm{~cm}$ with a mean $22.8 \pm 3.12 \mathrm{~cm}$. None of these fish passed through the pool and weir fish passage in Firnız Stream. PIT tagged $C$. damascina individuals started to ascend the vertical slot fish passage in Tekir Stream 10 days after tagging and the migration lasted 47 days between May $5^{\text {th }}$ and June $21^{\text {st }}, 2014$. The majority of the PIT-tagged fish passed through the fish passage between 03 A.M. to 06 A.M. during the early hours of the morning in May (Table 2). The total length of the PIT-tagged fish in Tekir Stream varied from 11.3 and $28.3 \mathrm{~cm}$ with a mean of $16.9 \pm 3.71 \mathrm{~cm}$ (Figure 4). A total of 24 of the 156 PIT-tagged fish ascended vertical slot fish passage in Tekir Stream. The ratio of the fish ascending the fish passage was $15.4 \%$. The total lengths of PIT-tagged fish ascending fish passage showed a variation in between 13.7 and 28.3 $\mathrm{cm}$ with a mean of $22.0 \pm 3.65 \mathrm{cms}$. The majority of PIT-tagged fish passing through the fish passage was over $20 \mathrm{~cm}$ in length. About 30 individuals of 156 PIT tagged fish were over $20 \mathrm{~cm}$ in length and 19 of these 30 fish (corresponding to 63.3\%) passed through the fish passage. Statistics indicate that the total lengths of the tagged fish passed through fish passage were not the same as the lengths of the tagged fish that didn't pass the passage $(t=9.061$, $\mathrm{df}=154 ; p=0.000)$. The passing ratio of large fish through the fish passage was greater than that of the small ones for PIT-tagged fish, as in the case of external-tagged fish.

Table 2. PIT-tagged Capoeta damascina passing through the vertical slot fish passage in Tekir Stream and their size and passing time.

\begin{tabular}{lcccc}
\hline Code of the PIT-tag & Total length $(\mathrm{cm})$ & Tagging date & Passing date & Passing time at: \\
\hline 989002000739977 & 20.0 & April 25, 2014 & May 5, 2014 & 13.11 .13 \\
989002000786586 & 24.1 & April 25, 2014 & May 7, 2014 & 03.38 .36 \\
989002000707037 & 19.4 & April 25, 2014 & May 8, 2014 & 02.54 .47 \\
989002000730687 & 22.8 & April 25, 2014 & May 10, 2014 & 04.43 .41 \\
989002000846289 & 17.2 & April 25, 2014 & May 13, 2014 & 08.41 .00 \\
989002000743689 & 25.4 & April 25, 2014 & May 13, 2014 & 04.18 .14 \\
989002000813556 & 21.1 & April 25, 2014 & May 14, 2014 & 05.19 .48 \\
989002000706514 & 20.1 & April 25, 2014 & May 14, 2014 & 04.14 .42 \\
989002000888935 & 27.6 & April 25, 2014 & May 15, 2014 & 03.05 .27 \\
989002000731766 & 23.2 & April 25, 2014 & May 15, 2014 & 06.05 .58 \\
989002000811670 & 24.4 & April 25, 2014 & May 15, 2014 & 06.38 .59 \\
989002000745787 & 22.4 & April 25, 2014 & May 15, 2014 & 12.28 .35 \\
989002000844208 & 21.2 & April 25, 2014 & May 15, 2014 & 03.05 .27 \\
989002000793608 & 21.9 & April 25, 2014 & May 15, 2014 & 06.52 .55 \\
989002000850454 & 25.5 & April 25, 2014 & May 16, 2014 & 04.37 .44 \\
989002000814027 & 16.5 & April 25, 2014 & May 18, 2014 & 15.50 .31 \\
989002000806163 & 28.3 & April 25, 2014 & May 20, 2014 & 04.15 .44 \\
989002000837818 & 15.6 & April 25, 2014 & May 22, 2014 & 03.50 .22 \\
989002000890309 & 22.3 & April 25, 2014 & July 06, 2014 & 18.01 .37 \\
989002000853416 & 13.7 & April 25, 2014 & June 07, 2014 & 17.51 .32 \\
989002000851300 & 25.2 & April 25, 2014 & June 12, 2014 & 07.52 .39 \\
989002000808502 & 24.5 & April 25, 2014 & June 18, 2014 & 06.33 .12 \\
989002000855120 & 23.7 & April 25, 2014 & June 20, 2014 & 06.21 .22 \\
989002000814586 & 22.6 & April 25, 2014 & June 21, 2014 & 06.24 .45 \\
\hline
\end{tabular}

\section{c) Radio telemetry}

A total of 47 fish were tagged with radio transmitters in Firniz Stream. These tagged fish were composed of 23 Salmo opimus, 3 Oncorhynchus mykiss, and 21 Capoeta damascina. Total lengths of the radio-tagged fish were between 22.5 and $42.0 \mathrm{~cm}$ with a mean $28.4 \pm 4.80 \mathrm{~cm}$ for $S$. opimus; the lengths were ranging from 29.0 and $33.0 \mathrm{~cm}$ with a mean of 
$30.7 \pm 2.1 \mathrm{~cm}$ for $O$. mykiss, and the lengths were between 26.0 and $38.3 \mathrm{~cm}$ with a mean of $31.2 \pm 3.3$ $\mathrm{cm}$ for $C$. damascina. None of the radio-tagged fish achieved to pass the pool and weir type fish passage in Firniz Stream. A total of 26 C. damascina were tagged with the radio transmitters in Tekir Stream. 2 of these fish died one week after being released. They were excluded during data processing (Table 3 ). The total lengths of 24 radio-tagged fish varied from 24.5 to $46.4 \mathrm{~cm}$ with a mean of $31.3 \pm 5.9 \mathrm{~cm}$ (Figure 4). 18 of these fishes (corresponding to 75\%) successfully passed vertical slot fish passage during the 83 days of April $28^{\text {th }}$ to July $20^{\text {th }}, 2013$. Six fish failed to enter the fish passage and were inhabited downstream (Table 3). Statistically, the sizes of the radio-tagged fish passed through the fish passage were shown to be no different from the fish that didn't pass $(t=0.324, \mathrm{df}=22 ; p=0.749)$.

Table 3. Radio-tagged Capoeta damascina individuals in Tekir Stream and their passing status through the vertical slot fish passage.

\begin{tabular}{|c|c|c|c|c|}
\hline Frequncies of the tag & Code of the tag & Total length $(\mathrm{cm})$ & Tagging date & Passing period \\
\hline 149.420 & 11 & 38.3 & April 04, 2013 & Dead \\
\hline 149.420 & 12 & 29.0 & April 04, 2013 & Dead \\
\hline 150.300 & 115 & 31.3 & April 16, 2013 & May 06 - May 15 \\
\hline 150.320 & 116 & 36.6 & April 16, 2013 & June 03 - June 07 \\
\hline 149.480 & 48 & 44.8 & April 23, 2013 & May 15 - May 23 \\
\hline 149.480 & 46 & 30.0 & April 23, 2013 & April 23 - April 28 \\
\hline 150.300 & 84 & 26.7 & April 23, 2013 & June 15 - June 23 \\
\hline 149.480 & 45 & 26.0 & May 01, 2013 & June 23 - July 08 \\
\hline 149.480 & 49 & 24.5 & May 01, 2013 & Did not pass \\
\hline 150.300 & 83 & 25.5 & May 01, 2013 & May 01 - May 06 \\
\hline 150.300 & 80 & 25.8 & May 01, 2013 & May 23 - June 03 \\
\hline 150.300 & 81 & 25.2 & May 01, 2013 & Did not pass \\
\hline 150.300 & 111 & 28.9 & May 01, 2013 & May 06 - May 15 \\
\hline 150.300 & 110 & 46.4 & May 06, 2013 & May 06 - May 15 \\
\hline 149.420 & 14 & 35.9 & May 06, 2013 & May 06 - May 15 \\
\hline 149.420 & 13 & 35.5 & May 06, 2013 & May 15 - May 23 \\
\hline 149.480 & 60 & 27.0 & June 03, 2013 & June 07 - June 15 \\
\hline 149.480 & 62 & 29.7 & June 03, 2013 & June 07 - June 15 \\
\hline 149.480 & 63 & 28.4 & June 03, 2013 & June 07 - June 15 \\
\hline 150.300 & 88 & 37.5 & June 07, 2013 & Did not pass \\
\hline 149.480 & 68 & 34.6 & June 07, 2013 & Did not pass \\
\hline 148.480 & 65 & 32.7 & June 07, 2013 & Did not pass \\
\hline 149.480 & 61 & 31.4 & June 07,2013 & June 23 - July 08 \\
\hline 150.300 & 103 & 30.0 & June 07, 2013 & June 15 - June 23 \\
\hline 150.300 & 104 & 29.0 & June 07, 2013 & Did not pass \\
\hline 150.300 & 101 & 27.0 & June 07, 2013 & July 08 - July 20 \\
\hline
\end{tabular}

Passage efficiencies of the vertical slot fish passage were found as $26.2 \%, 15.4 \%$ and $75.0 \%$ for T-Bar anchor tagged fish, PIT-tagged fish, and radio-tagged fish, respectively; and statistically, it was shown to vary depending on method adopted with application method $\left(X^{2}=40.290, \mathrm{df}=2, p=0.000\right.$. However, the dependence on the adopted method was found to be statistically insignificant with parameters of $X^{2}=5.824, \mathrm{df}=2, p=0.054$ for tagged fish with more than $20 \mathrm{~cm}$ in length.

No fish was detected in the trap and also no tagged fish passed through pool and weir fish passage in Firnız Stream. Therefore it was classified as nonfunctional. This was explained by the fact that no fish could reach to the fish passage because of obstructions of water intake structure of trout farms, and because of insufficient ecological flow rate.

\section{Discussion}

In Firnız Stream, no fish was detected in the trap installed into the pool and weir type fish passage. Further, no tagged fish passed through this fish passage. Therefore, it is suggested that the pool and weir fish passage in Firnız Stream was not functional. The most important causes of this failure are i) the insufficient environmental flow rate rather than the structural characteristics of the fish passage and ii) other obstructions in Firniz Stream. Three water intake structures of the trout farms that are present in Firniz Stream at the downstream of fish passage obstructed fish movements to the fish passage. It was also determined that insufficient water was supplied from the fish passage. Therefore, the ineffectiveness of the fish passage in Firniz Stream is related to attraction efficiency rather than passage efficiency. 
Only brown trout (Salmo opimus) inhabits at the stream where the fish passage is located and other cyprinids such as Capoeta damascina and Alburnus adanensis were not present in this area because of the low water temperature $\left(8-10^{\circ} \mathrm{C}\right)$.

The most important impacts of the construction of reservoirs are on the ichthyofauna, especially on migratory fish, by intercepting their migratory routes, altering the hydrological regime, and reducing spawning and nursery habitats (Wagner et al. 2012; Agostinho et al. 2004). Fish passages in Turkey have been constructed without the necessary scientific knowledge on the fish. Because, although more than 370 fish species inhabit Turkish inland waters (Kuru et al. 2014), Turkey has unfortunately not an inventory for migratory fish species. Besides, there is also a literature gap about the habitat usages and hydrological requirements of inland water fish in Turkey. Whereas, an effective fish passage design requires extensive integration of biological and hydraulic data in addition to other physical data (Castro-Santos et al. 2009).

The concept of the fish passage efficiency is related to both qualitative and also quantitative evaluations. The efficiency of fish passage is considered as a qualitative concept, which involves checking whether the system provides satisfactory passage for the target species, under the environmental conditions observed during the migratory period (Makrakis et al. 2011; Wagner et al. 2012). Quantitative assessments of efficiency take into account the percentage of fish present in one side of the passage that is can move through the fish passage (Larinier et al. 2002; Castro-Santos et al. 2009; Wagner et al. 2012). Fish passage efficiency is defined as attraction efficiency and passage efficiency (Calles and Greenberg 2005; Aarestrup et al. 2003; Larinier 2008). Attraction efficiency is the ratio between the number of individuals that were detected at each fishway entrance and the number that are released downstream. The passage efficiency is the ratio of successful to overall attempts to use a fishway (Bunt et al. 1999). The attraction of a fish passage depends on its location about the obstruction, particularly the location of its entrance and the hydraulic conditions near these entrances (Larinier 2008). In the present study, no fish was detected in the trap installed into the pool and weir fish passage in Firniz Stream. Also, no tagged fish also passed through the fish passage. Therefore, it is suggested that the pool and weir fish passage in Firnız Stream has not functionality. The most important cause of this failure is the insufficient environmental flow rate rather than the structural characteristics of the fish passage and because of other obstructions in Firniz Stream. Because of three water intake structures of the trout farms present in Firniz Stream at the downstream of fish passage and these obstructed fish movements to the fish passage. It also determined that insufficient water was supplied from the fish passage. Therefore, the ineffectiveness of the fish passage in Firniz Stream is related to attraction efficiency rather than passage efficiency. Only brown trout (S. opimus) inhabits at the stream where the fish passage is located and other cyprinids such as $C$. damascina and A. adanensis were not present in this area because of the low water temperature $\left(8-10^{\circ} \mathrm{C}\right)$. The efficiency of the vertical slot fish passage varied according to the methods applied (26.2\% in T\&Bar anchor tagged fish, $15.4 \%$ in PIT-tagged fish and $75.0 \%$ in radio-tagged fish). However, this difference was due to the size of the tagged fish. Because, when taking into account tagged fish with more than $20 \mathrm{~cm}$ in length, this difference among the applications was found insignificant and it was $47.5 \%$ for $\mathrm{T} \& \mathrm{Bar}$ anchor tagged fish, $63.3 \%$ for PIT-tagged fish and $75.0 \%$ for radio-tagged fish.

Different conclusions related to the efficiency of the fish passage have been reported in the literature. According to Agostinho et al (2002), citing to previous studies, from the 13 fish passages built on the dams lower than $16 \mathrm{~m}$ in South America, 10 fish passages had a functionality while 3 fish passages had not an efficiency. The height of the fish passages that have functionality varied from 5 to $16 \mathrm{~m}$, while the height of ineffective fish passages varied from 2 to $10.5 \mathrm{~m}$ (Agostinho et al. 2002). Strong swimming fish species were passed through the vertical slot fish passages at the power plants of Emsfor and Karlshammer in River Eman in Sweden (Clay 1995). The passage efficiency of the fish ways at Finsjo in River Eman was high for upstream migrating anadromous brown trout, with $89-100 \%$ success for ascending individuals (Calles and Greenberg 2005). Fish passage efficiency was reported as $55 \%$ for sea trout in a nature-like bypass channel in a small Danish stream (Aarestrup et al. 2003) and $88.5 \%$ in a fish passage (310 $\mathrm{m}$ in length and $15 \mathrm{~m}$ in height) at the Pitlochry Dam in Scotland (Gowans et al. 1999). In a pool and weir type fish passage that is $520 \mathrm{~m}$ in length and $20 \mathrm{~m}$ in height with an angle of $45^{\circ}$, in Parana River, Brazil, the proportions finding and entering the fish way differed between species, ranged from $7.4 \%$ (Prochilodus lineatus) to $55.4 \%$ (Piaractus mesopotamicus). Also, the proportion ratio of passing was different between species, ranged from $31 \%$ (Rhinelepis aspera) to $100 \%$ (Prochilodus lineatus) (Wagner et al. 2012). Passage efficiency in Lock and dam 1 fish passage that is 3.3 $\mathrm{m}$ in height in Cape Fear River was reported between 18 and 61\% (Moser et al. 2000). The efficiency of four fish passages located at small scale hydro plants on the Gave de Pau in the South-West of France was reported as 35.3\% (Baigts), 74\% (Sapso), 93.8\% 
(Artix) and 100\% (Biron) (Larinier 2008). Makrakis et al. (2011) reported that in the fish passage system known as Canal da Piracema, in Itaipu Hydroelectric Power Plant, with $10 \mathrm{~km}$ of extension and $120 \mathrm{~m}$ in height, only $0.5 \%$ of the migratory fish were able to reach the upstream sections of the channel. Attraction efficiency in a brush-type fish passage in Turkey was $22 \%$ for all fish species (Kucukali et al. 2019). Passage efficiency in this bruh-type fish passage was $67.07 \%$ for all fish species (55 individuals from 82 tagged fish passed the brush-type fish passage) (Kucukali et al. 2019).

As can be seen in these studies, the species studied exhibited different rates of passage and failure, both among species and between release sites and our results are actually are consistency with some of them. The low efficiencies were largly caused by the fishway design, fish behaviors, swimming performance of the species and other physical habitat factors. The swimming performance of the longdistance migratory species may reflect the differences in the ascension efficiency verified among species (Wagner et al. 2012). The behavior at fishway and swimming capacity of Turkish migratory fish species are unknown, and they should be conducted on as much as possible to support studies on fish passages.

In the present study, male $C$. damascina individuals passed through the fish passage earlier than females while towards the end of migration females became dominant. Male American shads do initiate spawning migrations earlier in the season and are smaller than females (Moser et al. 2000; Davis 1980). Capoeta damascina individuals passed the fish passage at night or early morning. This was corroborated by many studies for fish. The majority of the sockeye salmon passed the Seton Dam fishway during the night hours, however, pink salmons passed during the day (Pon et al. 2006).

Consequently, $C$. damascina and A. adanensis that are the most common fish species in River Ceyhan easily used vertical slot fish passage, however, no fish passed through the pool and weir type fish passage. To be able to design more effective fish passages, migratory species, and their habitat usages and swimming performances should be determined in Turkey.

\section{Acknowledgments}

This study is a part of the project (Project no: 112T266) funded by TUBITAK (The Scientific and Technological Research Council of Turkey) under the COST FA 1304 action. It was presented as an oral presentation in Fish Passage 2015: International conference on river connectivity best practices and innovations in Groningen, the Netherlands. We gratefully acknowledge TUBITAK for financing the project. We also thank Gerd Marmulla who was the advisor of the project and Eva Bonsak Thorstad, Finn Okland and Etienne Baras for their contributions, especially on telemetry studies.

\section{References}

Aarestrup K, Lucas M, Hansen JA. 2003. Efficiency of a nature- like bypass channel for sea trout (Salmo trutta) ascending a small Danish stream studied by PIT telemetry. Ecol Freshw Fish. 12(3):160-168. doi:10.1034/j.1600-0633.2003.00028.x

Agostinho AA, Gomes LC, Fernandez DR, Suzuki HI. 2002. Efficiency of fish ladders for neotropical ichthyofauna. River Res Appl. 18(3):299-306. doi:10.1002/rra.674

Agostinho AA, Gomes LC, Veríssimo S, Okada EK. 2004. Flood regime, dam regulation and fish in the Upper Paraná River: effects on assemblage attributes, reproduction and recruitment. Rev Fish Biol Fisher. 14(1):11-19. doi:10.1007/s11160-004-3551-y

Agrin Co Ltd. 1999. Aslantas Dam and related aspects of the Ceyhan River basin, Turkey. A WCD case study prepared as an input to the World Commission on Dams, Cape Town. [son erişim: 5.09.2019]. http://dams.org/kbase/studies/tr

Alp A, Akyüz A, Özcan M, Yerli SV. 2018. Assessment of movements and habitat use of Salmo opimus in Firnız stream, river Ceyhan of Turkey using radio telemetry techniques. Environ Biol Fish. 101(11):1613-1624. doi:10.1007/s10641-018-0807-2

Brown JJ, Limburg KE, Waldman JR, Stephenson K, Glenn EP, Juanes F, Jordaan A. 2013. Fish and hydropower on the US Atlantic coast: failed fisheries policies from half- way technologies. Conserv Lett. 6(4):280-286. doi:10.1111/conl.12000

Buck WO. 1906. The Fishway at Grand Lake Stream. T Am Fish Soc. 35(1):233-236. doi:10.1577/15488659(1906)36[233:TFAGLS]2.0.C $\mathrm{O} ; 2$

Buck WO. 1913. Fishways for the Rank and File. T Am Fish Soc. 42(1):101-114. doi:10.1577/15488659(1912)42[101:FFTRAF]2.0.C $\mathrm{O} ; 2$

Bunt CM, Katopodis C, McKinley RS. 1999. Attraction and passage efficiency of white suckers and smallmouth bass by two Denil fishways. N Am J Fish Manage. 19(3):793-803. doi:10.1577/15488675(1999)019<0793:AAPEOW>2 .0.CO;2

Bunt CM, Castro-Santos T, Haro A. 2012. Performance of fish passage structures at upstream barriers to migration. River Res Appl. 28(4):457-478. doi:10.1002/rra.1565

Calles EO, Greenberg LA. 2005. Evaluation of naturelike fishways for re- establishing connectivity in 
fragmented salmonid populations in the river Emån. River Res Appl. 21(9):951-960. doi:10.1002/rra.865

Castro-Santos T, Cotel A, Webb PW. 2009. Fishway evaluations for better bioengineering: an integrative approach. In Challenges for diadromous fishes in a dynamic global environment. American Fisheries Society, Symposium.69: 557-575 pp.

Castro-Santos T, Haro A, Walk S. 1996. A passive integrated transponder (PIT) tag system for monitoring fishways. Fish Res. 28(3):253-261. doi:10.1016/0165-7836(96)00514-0

Cheney AN. 1898. Fishways, their construction and use. Third Annual Report to the Commissioners of Fisheries, Game, and Forests of the State of New York, 222.

Clay CH. 1995. Design of fishways and other fish facilities. Lewis Publishers: Boca Raton.

Davis SM. 1980. American shad movement, weight loss and length frequencies before and after spawning in the St. Johns River, Florida. Copeia. 1980(4):889-892. doi: $10.2307 / 1444476$

DSI. 2013. Balık geçitlerinin planlanmasında balık faunasının tespiti ve balık geçidi temel kriterlerinin belirlenmesi projesi. Solaklı ve Yanbolu Dereleri Sonuç Raporu. DSI Genel Müdürlüğü, Ar-Ge Yayın no: 2, Ar-GE Proje no:2011/2. [in Turkish]

Dyche LL. 1912. Regarding fishways and dams. T Am Fish Soc. 41(1):301-306.

Fredrich F, Ohmann S, Curio B, Kirschbaum F. 2003. Spawning migrations of the chub in the River Spree, Germany. J Fish Biol. 63(3):710-723. doi: 10.1046/j.1095-8649.2003.00184.x

Gowans ARD, Armstrong JD, Priede IG. 1999. Movements of adult Atlantic salmon in relation to a hydroelectric dam and fish ladder. J Fish Biol. 54(4):713-726. doi:10.1111/j.1095-8649.1999.tb02028.x

Jackson DC, Marmulla G. 2001. The influence of dams on river fisheries. FAO Fisheries Technical Paper (419), 1-44.

Jepsen N, Schreck C, Clements S, Thorstad EB. 2005. A brief discussion on the $2 \%$ tag/bodymass rule of thumb. Aquatic telemetry: advances and applications, proceedings of the fifth conference on fish telemetry held in Europe. Ustica, Italy. [Cited: 2019 Nov 15]. Available from http://www.fao.org/tempref/docrep/fao/008/y5999e/y 5999e25.pdf

Kara C, Alp A, Şimşekli M. 2010. Distribution of fish fauna on the upper and middle basin of Ceyhan River, Turkey. Turk J Fish Aquat Sc. 10(1):111-121. doi: 10.4194/trjfas.2010.0116

Katopodis C, Williams JG. 2012. The development of fish passage research in a historical context. Ecol Eng. 48(2012):8-18. doi:10.1016/j.ecoleng.2011.07.004

Kuru M, Yerli SV, Mangit F, Ünlü E, Alp A. 2014. Fish biodiversity in inland waters of Turkey. Journal of Academic Documents for Fisheries and Aquaculture. 1(3):93-120.
Kucukali S, Verep B, Alp A, Turan D, Mutlu T, Kaya C, Yıldırım Y, Toreyin BU, Özelçi D. 2019. Flow structure and fish passage performance of a brush-type fish way: a field study in the İyidere River, Turkey. Mar Freshwater Res. 70(11):1619-1632. doi:10.1071/MF18242

Larinier M. 2000. Dams and fish migration. World Commission on Dams. FAO Fisheries Technical Paper (419), 45-89.

Larinier M, Travede F, Porcher JP. 2002. Fishways: biological basis, design criteria and monitoring. B Fr Peche Piscic. 364 suppl., 208 p.

Larinier M. 2008. Fish passage experience at small-scale hydro-electric power plants in France. Hydrobiologia. 609(1):97-108. doi:10.1007/s10750-008-9398-9

Lucas MC, Mercer T, Armstrong JD, McGinty S, Rycroft P. 1999. Use of a flat-bed passive integrated transponder antenna array to study the migration and behaviour of lowland river fishes at a fish pass. Fish Res. 44(2):183-191. doi: 10.1016/S0165-7836(99)00061-2

Lucas MC, Bubb DH. 2005. Seasonal movements and habitat use of grayling in the UK. Environment Agency Report SC030210/SR, Bristol.

Makrakis S, Miranda LE, Gomes LC, Makrakis MC, Junior HMF. 2011. Ascent of neotropical migratory fish in the Itaipu reservoir fish pass. River Res Appl. 27(4):511-519. doi:10.1002/rra.1378

Marmulla G. 2001. Dams, fish and fisheries: opportunities, challenges and conflict resolution FAO Fisheries Technical Paper. No. 419. Rome, 166p.

Moser ML, Darazsdi AM, Hall JR. 2000. Improving passage efficiency of adult American shad at lowelevation dams with navigation locks. N Am J Fish Manage. 20(2):376-385. doi: $10.1577 / 15488675(2000) 020<0376$ :IPEOAA $>2$. 3. $\mathrm{CO} ; 2$

Pon LB, Cooke SJ, Hinch SG. 2006. Passage efficiency and migration behaviour of salmonid fishes at the Seton Dam Fishway. Final report for the Bridge Coastal Restoration Program, Project 05.Se.01.

Prince EE. 1914. A Perfect Fish Pass: Some suggestions as to defects in fish passes and how to overcome them. T Am Fish Soc. 43(1):47-56. doi:10.1577/1548-8659(1913)43[47:APFP]2.0.CO;2

Ramstad KM, Woody CA. 2003. Radio tag retention and tag-related mortality among adult sockeye salmon. N Am J Fish Manage. 23(3):978-982. doi:10.1577/15488675(2003)023<0978:RTRATM >2 .0. $\mathrm{CO} ; 2$

Reagan RE, Adams N, Rondorf D, Fitzgerald G, Spateholts B, Hoffman T, Olson D. 2005. Distribution, migration behavior, habitat use, and species interactions of fall-released juvenile hatchery spring Chinook salmon in the Deschutes River, Oregon, 2003. Annual report for 2003. U.S Fish and Wildlife Service. 42p.

Riley WD, Ibbotson AT, Beaumont WRC, Rycroft P, Cook AC. 2010. A portable, cost effective, passthrough system to detect downstream migrating 
salmonids marked with $12 \mathrm{~mm}$ passive integrated transponder tags. Fish Res. 101(3):203-206. doi:10.1016/j.fishres.2009.10.003

Rogers WH. 1892. Fishways. T Am Fish Soc. 21(1):127135.

Roscoe DW, Hinch SG. 2010. Effectiveness monitoring of fish passage facilities: historical trends, geographic patterns and future directions. Fish Fish. 11(1):12-33. doi: 10.1111/j.1467-2979.2009.00333.x

Tanrıverdi Ç, Alp A, Demirkıran AR, Üçkardeş F. 2010. Assessment of surface water quality of the Ceyhan River basin, Turkey. Environ Monit Assess. 167(14):175-184 doi: 10.1007/s10661-009-1040-4

Thorsteinsson V. 2002. Tagging methods for stock assessment and research in fisheries. Report of concerted action FAIR CT.96.1394, 179p.

Thorstad EB, Rikardsen AH, Alp A, Økland F. 2013. The use of electronic tags in fish research- an overview of fish telemetry methods. Turk J Fish Aquat Sc. 13(5):881-896. doi:10.4194/1303-2712-v13 513

Wagner RL, Makrakis S, Castro-Santos T, Makrakis MC, Dias JHP, Belmont RF. 2012. Passage performance of long-distance upstream migrants at a large dam on the Paraná River and the compounding effects of entry and ascent. Neotrop Ichthyol. 10(4): 785-795. doi:10.1590/S1679-62252012000400011

Williams JG, Armstrong G, Katopodis C, Larinier M, Travade F. 2012. Thinking like a fish: a key ingredient for development of effective fish passage facilities at river obstructions. River Res Appl. 28(4):407-417. doi:10.1002/rra.1551

Worrall J. 1874. The Fishways of Pennsylvania. T Am Fish Soc. 3(1):38-44.

doi:10.1577/1548-8659(1874)4[38:TFOP]2.0.CO;2 